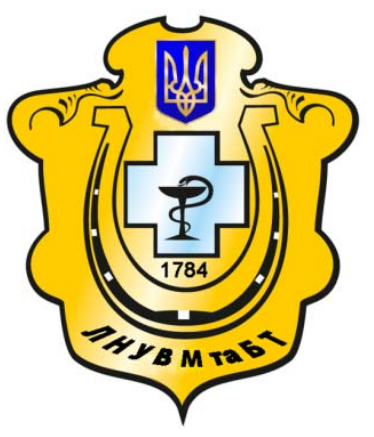

Науковий вісник Львівського національного університету ветеринарної медицини та біотехнологій імені С.3. Гжицького

Scientific Messenger of Lviv National University of Veterinary Medicine and Biotechnologies named after S.Z. Gzhytskyj

doi:10.15421/nvlvet7201

ISSN 2413-5550 print

ISSN 2518-1327 online

http://nvlvet.com.ua/

\title{
Diagnosis of persistent BVD in one day old and older than 30 days calves with Rapid Kit Tests
}

\author{
Durmus Kahraman ${ }^{1}$, Sima Sahinduran ${ }^{2}$ \\ sahinduran@mehmetakif.edu.tr \\ ${ }^{1}$ Insitute of Health Sciences, Mehmet Akif Ersoy University, Burdur/Turkey \\ ${ }^{2}$ Department of Internal Medicine, Faculty of Veterinary Medicine, Mehmet Akif Ersoy University, Burdur Turkey
}

Bovine Viral Diarrhoea (BVD) is an important disease of cattle which causes alimentary, respiratory and reproductive disorders and serious economic losses. Today, eradication of disease is compulsory for the increase of dairies and achieving more healthier herds. In cattle, if the calves are infected with BVD from the uterus in the first trimester of pregnancy, they are born persistent infected (PI) antigen(+). The PI calves are smaller or normal in apperance than normal calves. Persistent infected (PI) calves spread the virus throughout their lives and infect their surroundings. BVD causes early embrionic death, calves born with anomalies and immunosuppression in infected animals.

In this study 200 calves between 1-30 days old from Burdur province are screened with BVD rapid test kit. In the screening, 13 calves $(6.5 \%)$ are found BVDV ag(+). The gender of PI calves are found $4 \%$ female $(8 / 200)$ and $2.5 \%$ male $(5 / 200)$. In the $5 \%$ of PI calves (10/200), respiratory and alimentary problems were clinically seen. The antigen(+) animals are put out of the herd and vaccination protocols are recommended.

In this study, diagnosing the disease can be made rapidly by both clinicians and farmers, also putting the virus spreading persistent calves out of herd without losing time and a successful struggle can be made against BVD, are shown.

Key words: bovine viral diarrhoea, calf, rapid test kit

This study is summary of MS Thesis of Durmus Kahraman and supported by Mehmet Akif Ersoy University, Scientific Research Project Council (Project Number: 0242-YL-14).

\section{Bir günlük ve 30 günlükten büyük buzağilarda persiste bvd hastaliğinin hizli kit testleri ile teşhisi}

Bovine Viral Diarrhoea (BVD) siğırlarda sindirim, solunum ve üreme sistemi problemlerine neden olan ve ciddi ekonomik kayıplarla sonuçlanan önemli bir hastalıktır. Günümüzde modern damızlık süt işletmelerinin artması nedeniyle sağlıklı sürüler elde edilmesi için hastalıkların eradike edilmesi gerekmektedir. Siğırlarda gebeliğin ilk trimestrinda anne uterusundan alınan BVD virüsü fötüsü enfekte ederek persiste enfekte antijen (+) yavruların doğmasına sebep olmuştur. Persiste enfekte (PI) doğan buzağllar sağllklı buzağılardan daha küçük ya da normal görünüște olabilmektedir. Bu buzağılar ömürleri boyunca virüsü saçarak etrafienfekte ederler. BVD virüsü, enfekte annelerin yavrularınada erken embriyonik ölümler, anomali buzağ doğumlarl ve immun supresyonun neden olduğu ölümlere siklıkla rastlanmaktadır.

Bu çalışmada, Burdur ilindeki bir günlük ve otuz günlükten büyük 200 buzăğ BVD hızlı test kitleri ile taranmıştır. Çalışmamızda 13 adet hayvan BVDV ag(+) olarak saptandı (6.5\%).PI hayvanların 4\%'ü dişi (8/200), 2.5\%'u ise (5/200) erkek olarak tespit edildi. PI BVD'li buzağlların 5\%'inde (10/200) klinik olarak solunum ve sindirim problemleri ve gelişme geriliği görüldü. Tarama sonucunda antijen pozitif olan hayvanlar hemen sürüden çıkarılarak sürülere aşılama uygulamalarının yapılması önerildi.

Yaptığımız çalışmada hızlı test kiti kullanılarak hem sahada çalışan Veteriner Hekimlerin hem de üreticilerin pratik olarak BVD teşhisini yapabileceği saptandı ayrıca virüs saçan persiste buzağıların zaman kaybetmeden sürüden uzaklaştırılması ve BVD enfeksiyonuyle başarı ile mücadele yapılabilmesi için hızlı testlerin kolay ve kesin sonuçlar verdiği gösterildi.

Anahtar kelimeler: bovine viral diare, buzăgl, hızlı test kiti

\section{Citation:}

Durmus, Kahraman, Sima, Sahinduran (2016). Diagnosis of persistent BVD in one day old and older than 30 days calves with Rapid Kit Tests. Scientific Messenger LNUVMBT named after S.Z. Gzhytskyj, 18, 4(72), 96-106. 


\section{Giriş}

Bovine Viral Diare (BVDV) hastalığı ilk kez Olafson ve Rickard (1947) tarafından tanımlanmıştır (64). BVDV enfeksiyonu dünya çapında sığırlarda endemik olarak görülmekte ve büyük ekonomik kayıplara yol açmaktadır $(67,68,69,128,129)$. Bu kayıplar enfekte sürülerde virüsün üreme ve genel sağlık durumlarında oluşturduğu negatif etkiler sonucu oluşur $(90,128)$.

BVDV enfeksiyonu sığırlarda klinik olarak sindirim ve genital sistemini etkileyerek sığır yetiştiriciliğinde büyük kayıplara neden olan multisistemik viral bir enfeksiyondur $(95,126)$. Prevalansı $50-90 \%$ arasinda değişen BVDV enfeksiyonunun immunsupresyon, döl tutmama problemleri, abort ve mumifikasyon, konjenital defektler, immuntolerans, persiste enfeksiyon (PI) ve mukozal disease (MD)'e neden olduğu bildirilmiştir (113). BVDV enfeksiyonu sonucunda buzağılarda mikroensefali, hidrosefalus, proensefali, serebellar hipoplazi ve hipomyelizasyon gibi konjenital defektler sıklıkla gelişebilmektedir. Ayrıca katarakt, mikroftalmi, optik noritis, retinal dejenerasyon, timik hipoplazi, hipotrikozis, alopesi, bukleli kıl örtüsü, sırtlan hastalığı, osteojenezde bozulma, alt çene kısalığı ve gelişme geriliği daha nadir olarak görülen konjenital defektler arasında sayılabilir (119).

BVDV enfeksiyonu subklinik seyirli olabileceği gibi ateş, diyare, süt veriminde ani azalma, fertilite problemleri, oral, nazal akıntılar, ağız boşluğunda erozyon ve ülser gibi lezyonlar görülmekle birlikte ölümcül mukozal hastalığa kadar değişen hastalık tablosuyla seyredebilmektedir (8).

Bu tez çalışmasıyla Burdur ili büyükbaş işletmelerinde bulunan kolostrum emmemiş ve 30 günlük yaştan büyük 200 buzağının BVDV hastalığı yönünden persiste enfekte olup olmadıklarının araştırılması amaçlanmıştır.

\section{Genel bilgiler}

\section{Etiyoloji}

Hastalık koyunlarda görülen Border hastalığı ve domuzlarda domuz ateşi hastalığına neden olan virüsler ile benzer ailedendir (45). Virüs Flaviviridae ailesinin Pestivirus cinsindendir $(26,59,97)$. Bovine Viral Diyare Virüsü (BVDV), özellikle ruminantları enfekte eden, önemli ve patojen heterojen virüslerin bulunduğu $(5,55$, $81,128)$ gruptandır. Virüs nispeten küçük (40-60 nm), zarflı ve küresel yapıda, tek sarmallı, pozitif yönlü, iki genotip veya tür (BVDV-1 ve -2) ile genetik olarak en az 13 alt türe ayrılan bir RNA virüsüdür $(5,39,55,128$, 134). Bu biyoçeşitliliğe rağmen tüm BVD virüsleri hücre kültürlerindeki etkilerine göre sitopatojenik (cp) veya nonsitopatojenik (ncp) olmak üzere iki biyotipe ayrılır (32).

Ncp suşlar persiste olmaya adaptedirler ve cp suşlarınınaksine fetüste tip I interferon oluşumunu engelledikleri için bu ismi almışlardır (22, 31). Sitopatojenite yap1sal olmayan NS2/3 proteinini kodlayan bölgede oluşan genetik değişimlerin (eklenmeler, duplikasyonlar ve/veya yeniden düzenlemeler) sonucunda ortaya çıkar. $\mathrm{Bu}$ tarz mutasyonlar mukozal hastalık denilen terminal dönemin gelişmesiyle bağlantılıdır (77). Genelde her iki genotip de benzer patojeniteye sahiptir.
Ancak tip II suşu yüksek morbidite ve mortalite ile seyreden şiddetli akut BVDV enfeksiyonu ile ilişkilendirilmektedir (47,102, 116). Genotip içerisinde yüksek derecede heterojenite olmasına rağmen BVDV suşlarının genelde sürüye özgü olduğu gösterilmektedir $(60,84,109,143)$. Bu durum sürüden izole edilen virüsün, başka bir suş tekrar sürüye bulaşmadığg sürece daha iyi tanımlanabilmesi anlamına gelir. BVDV'ye karşı bağışık olmayan hayvanlarda klinik tablo olarak ateş, iştahsızlık ve mukozal lezyonlar ortaya çıkabilir. BVDV hücresel düzeyde bağışıklığa hasar verdiği için sekonder olarak buzağılarda öksürük veya ishal görülebilir (81). Erişkin boğalarda akut enfeksiyon sırasında sperma kalitesi geçici olarak bozulabilir (74). Virüs hızlı bölünen hücrelere affinite gösterir. $\mathrm{Bu}$ yüzden büyümekte olan fetüs replikasyon için oldukça uygundur. Hastalığa bağışık olmayan gebe hayvanlarda virüs yavruyu $\% 100$ etkiler (42). Fetal enfeksiyonun spesifik klinik tablosu ise gebelik sürecine bağlıdır ve enfekte sürülerde bu nedenden dolayı geniş çapta üreme problemleri görülebilir (118). $\mathrm{Bu}$ durum gebe kalamama, immuntolere, persiste enfekte (PI) buzağıların doğması, malformasyonlar, fetal ölüm ve abort veya mumifikasyon, intrauterin büyümede gecikme ve güçsüz veya ölü doğumları içerir $(29,45,5,89,101,138)$. Abortlar gebeliğin herhangi bir döneminde meydana gelebilir ve enfeksiyon zamanıyla bağlantılı değildir (81).

Persiste Enfekte (PI)

Fetüsün gebeliğin ilk trimesterinde immun sistemi gelişmeden önce enfekte olması persiste enfeksiyonla (PI) sonuçlanır (38). PI hayvanlar enfeksiyonun yayılmasında ve vücut sıvılarıyla yüksek miktarlarda sürekli virüs saçılışında anahtar taşıyıcılardır $(20,34,75,88,91,140$, 141, 142). Tipik olarak persiste enfeksiyonlarda belirgin antikor yanıtı oluşmaz ancak BVDV'nin heterolog suşlarına maruz kalınırsa nötralize edici antikorlar oluşabilir $(15,24)$. Spesifik nötralize edici antikorların varlığı bu durumdaki hayvanlardan virüsün izole edilmesini etkileyebilir (19). PI hayvanlar bozulmuş immun yanıta sahiptir ve diğer enfeksiyonlara da yakalanmaya daha yatkındırlar (110). Bundan dolayı erişkin yaşa gelmeden önce ölür veya kesime sevk edilirler $(9,65,132)$. Ancak klinik olarak sağlıklı olan hayvanlar da görülebilir ve erişkin yaşa ulaşıp gebe kalabilirler (88). Eğer böyle olursa enfeksiyon fetüse aktarılır ve böylece yavru sürekli PI kalır (7).

Fetüs immun sistemi geliştikten sonra enfekte olursa antikor geliştirebilir (71). Ancak immun yanıt oluşturma yeteneğine rağmen, büyümekte olan fetüs negatif olarak etkilenir ve bu hayvanlar doğuştan güçsüz, hasta görünüşlü ve enfeksiyonlara daha duyarlı olarak doğarlar (79, 93). Gebe düve eğer PI değilse enfeksiyona yanıt olarak antikor geliştirir ve fetüste persiste enfeksiyon gerçekleşmişse onun da immun yanıtı tetiklenir. Böylece antikor düzeyi doğumdan kısa süre önce kolostrum üretimi başlayana kadar yükselir $(23,91)$. Bu fenomen tanısal amaçla PI buzağı doğurma riskine sahip ineklerin belirlenmesinde kullanılır (83).

BVDV'ye karşı antikor içeren kolostrumla beslenen buzağılar hayatlarının ilk aylarında kendilerini enfeksiyondan koruyan pasif bağışıklığı elde etmiş olurlar $(16,33,70,98)$. Bu koruyuculuğun süresi kolostrumdaki 
nötralize edici antikorların konsantrasyonuna, içirilen kolostrum miktarına ve buzağının hastalığı atlatma olasılığına bağlıdır. PI hayvanlarda maternal antikorlar daha hızlı azalış gösterir $(19,106)$. Maternal antikor titresi yüksek iken BVDV ile karşı karşıya kalan buzağılar hastalığa karşı koruyucu maternal antikorları kullanır, maternal antikorları geliştirir ancak yeniden enfeksiyona maruz kaldiğında serumda koruyucu antikor bulunmayabilir $(115,117)$.

\section{Mukozal Hastalık}

Mukozal hastalık (MD), persiste enfeksiyon sonucu 6 ay ile 2 yaş arasındaki sığırlarda ortaya çıkar. Hastalığın bu evresi 2 gün ile 3 hafta süre içerisinde ortaya çıkabilen akut veya 18 aylık yaşa kadar hayatta kalabilen kronik şekilde olabilir. Vakalar tipik olarak ateş, iştahsızlık, gastrointestinal kanalda şiddetli mukozal erozyonlar, zafiyet ve ölüme götüren yoğun ishal ile seyreder (8). Kronik vakalarda hayvanlar daha uzun süre benzer belirtiler gösterir. Aralıklı ishal ve kronik timpani gibi gastrointestinal belirtilerden başka aynı zamanda deride eroziv lezyonlar ve laminit gelişebilir (81).

Mukozal hastalık (MD), 4a genomu yapısal olmayan bölgesinde oluşan mutasyon sonucunda ncp'den cp'ye dönüşümüyle gelişir $(77,103,131)$. Eğer cp suşu ncp suşu ile homolog ise PI buzağı buna karşı nötralize edici antikor üretmez. $\mathrm{Bu}$ nedenle sürüye spesifik bir suş yerleştiğinde, cp suş sürüdeki diğer PI hayvanlara da bulaşır ve salgın oluşabilir. Bu durumda klinik vakalardan homolog ncp ve cp suşlar izole edilebilir (87). MD aynı zamanda persiste ncp suş ile dışarıdan gelen cp suş arasında oluşan rekombinasyonun sonucunda da gelişebilir. Bu durum örneğin, cp suşları içeren aşılar kullanıldığında ortaya çıkar (8).

BVDV hem direk, hem de indirek olarak hayvanlara bulaşabilmektedir. Direk bulaşma PI hayvanla temas sonucu gerçekleşebilir (81). İndirek bulaşma ise bulaşma zaman1, 1sı ve virüs miktarına bağlıdır. Sürüde PI hayvan olması durumunda virüs, enfekte aborte fetüs veya plasenta, kapalı ahırlarda ortamın havası, rektal palpasyon, kontamine kulübeler ve enjektörler yoluyla bulaşabilir $(57,78,82,86)$. Virüs akut enfekte veya PI boğadan alınmış spermada, kontamine embriyoda, kontamine enjektör veya suni tohumlama kateterlerlerinde mevcutsa, saçılım potansiyeli artış gösterir (54, 75, 99, 126). Sürü içi ve sürüler arası bulaşmada en tehlikeli etken PI hayvan alımı veya PI buzağı taşıyan ineklerin sürü içerisine dâhil edilmesidir (81). BVDV kontrolü yapılmayan sürülerle aynı merayı paylaşan başka sürülerdeki gebe hayvanlara da bulaşma şekillenebilir (61, 121, 122). Akut enfeksiyonlarda sürüdeki yayılım sınırlanabilse de enfeksiyonun yerleşik hal almasında erken gebe hayvanların (PI buzağı doğumuyla sonuçlanır) varlığı önemli rol oynar (81). BVDV'nin diğer evcil ve yabani çift tırnaklıları da etkilediği bilinmektedir (11, 40,139). Persiste enfeksiyonun varlığ 7 türde (koyun, domuz, alpaka, beyaz kuyruklu geyik, eland, fare geyiği ve Amerikan dağ keçisi) gözlenmiştir (30, 96, 107, 125, 133, 136, 144). Sı̆̆ır hariç bulaşmada BVDV ile Border hastalığı virüsüaynı aileden olduğu için koyunların rezervuar olarak rol oynayabileceği ortaya konmuştur (27, 28). Bachofen ve arkadaşları (2013) PI bir buzağıyla aynı ortamda barındırılan bir keçiden BVDV ile PI oğlak elde ettiklerini bildirmişlerdir. Elde ettikleri oğlak seronegatif gebe keçilerle aynı ortamda bırakılmış, gebe keçilerden elde edilen oğlaklar da PI olarak doğmuşlardır.

$\mathrm{Bu}$ durum BVDV'nin keçi popülasyonunda PI sı̆̆ır olmasa bile persiste olarak varlığını sürdürdüğünü ve viral genomun taşıyıcı türlerde adapte olmaya başladığını düşündüren önemli bir bulgu olmuştur.

Yapılan çalışmalarda tüm sığır popülasyonu içerisinde PI hayvanların görülme sıklığının (enfekte ve enfekte olmayan sürüler dahil) 1-2\% civarında olduğu tespit edilmiştir $(17,37,66,127)$. Gebeliğin ilk trimesterinde ise tahmini enfeksiyon oranının tüm popülasyonda $3,3 \%$ olduğu bildirilmiştir (66).

BVDV için testlerde virüsün kendisi (viral RNA'nın izi dahil) veya ona karşı olan antikorun bulunması hedeflenir. Teşhis araçları genel olarak bireysel teşhis için kullanılır ancak bazıları sürü bazında teşhis için de kullanılır. $\mathrm{Bu}$ testler temelde antijen ve antikor varlığını tespit etme esasına dayanır. Antijen tayininde virüs izolasyonu (VI), ELISA ve RT-PCR kullanılırken, antikor tayininde direk ve indirek ELISA ile virüs nötralizasyon testleri kullanılmaktadır $(4,41,81,112,114,120)$.

Virüs izolasyonu (VI) primer sığır böbrek hücresi, konha veya testis gibi hücrelerde virüsün varlığını tespit etmek için florokrom veya enzim işaretli BVDV spesifik antikorların kullanıldığı düşük pasajlama ile yapılır. VI virolojik teşhis için referans testtir ve canlı enfeksiyon virüsünün varlığını belirlemede iyi bir yöntemdir (18). Viral antijenin ELISA ile tespiti için birçok yöntem geliştirilmiştir $(10,35,48,49,50,56,76,92)$. Bu tür testler hızlı, duyarlı ve hücre kültürlerinden bağımsız olduklarından sık kullanılmaktadır. Çoğu sandviç tiptedir. Test tabanında antikor ve peroksidaz gibi dedektör antikorlar vardır. Bazı testler sirasında, viral antijen hayvandan alınan tam kan örneklerinden hazırlanan buffy coat (lökosit birikimi olan ince beyaz tabaka) içerisinde aranmakta, buffy coat oluşumu için gereken numune miktarı fazla olduğu için az miktardaki numune problem yaratmaktadır. Ancak geliştirilmekte olan yeni antijen ELISA kitleri, antijen ekstrakte etme prensibine dayanmaz (63). Immunohistokimya yöntemleri intraselüler viral antijenin saptanması için kullanılabilir $(58,62)$. Örnekleme için kulaktan alınan doku parçasının kullanımı da PI hayvanların tespit edilmesini sağlar (100). Viral RNA'nın teşhisi için reverse transkriptaz polimeraz zincir reaksiyonu (RT-PCR) teknikleri de geliştirilmiştir. Alınan örnekteki toksik içeriğe karşı duyarsız olması ve benzer antikorların varlığını ortaya koymasıyla avantajlı, ancak herhangi bir durumda örnek kontamine olduğunda yanlış pozitif verebilecek kadar da hassastır (12). Ancak BVDV nükleik asit amplifikasyonu ve teşhisinin aynı tüpte yapıldığ kapalı RT-PCR sistemlerinin geliştirilmesi yanlış pozitiflik sorununu çözmüştür (85). Bugün kantitatif ve daha kapsamlı testlerin geliştirilmiş olması, genotiplerin veya ek viral ajanların aynı örnekten saptanmasını sağlamaktadır $(53,104)$. Antikor varlığının tayini için altın standart test virüs nötralizasyon testidir (46). Bu yöntemin sensitivite ve spesifitesi iyidir ancak hücre kültürüne ihtiyaç duyar ve ELISA ile karşılaştırıldığında işçilik oldukça fazladır. $\mathrm{Bu}$ yöntem çok miktarda örnek alındığında kullanılabilir. 
BVDV'den korunmada aşılamanın önemi fazla olmasına rağmen sürünün bağışıklık durumu ve PI hayvanların varlığı belirlenmeden aşılama yapılması sonucu yetersiz immunite oluşması veya hastalığın sürülerde ortaya çıkmasına neden olmuştur. Kullanılan aşı tipi (canlı ya da attenüe) de hastalığın açığa çıkmasına yol açabilir. Buna rağmen ölü aşıların kullanımı daha güvenlidir $(80,81,108,135)$. Hastalıktan korunmada çeşitli ülkelerin geçmişte uyguladıkları eradikasyon programları hastalığın görülme sıklığını azaltmış ve PI buzağı kontrolünde başarılı olmuștur. Test ve kesime sevk uygulamaları uzun vadede uygulandığında aşılama yapılmadan da BVD' ye karşı mücadele edilebileceği bildirilmektedir. Hastalığın tanımlanmasının üzerinden yıllar geçmesi ile hastalığın yol açtığı olumsuz etkilerini kontrol etmek için çok sayıda aşıların geliştirilmesi yanına aynı zamanda eradikasyon programları da önem kazanmıştır. Bu programlar enfekte sürülerin belirlenmesi ve bunu takiben persiste hayvanların sürüden çıkartılmasından ibarettir $(2,13,14,111,146)$.

Ülkemizde daha önce yapılan çalışmalarla BVDV'nin varlığı ortaya konmuştur $(1,3,73,105,130)$. Gelfert (1991) tarafından yapılan geniş çaplı Türkiye taramasında ise, sığırlar arasında BVDV'nin prevalansı \%60 olarak tespit edilmiştir. Daha önce yapılmış çalışmaların çoğu serolojik veya virüsizolasyon temellidir. Serolojik testlerin duyarlığı düşük ve elde edilen sonuçlar yoruma açıktır. Virus izolasyonu temelli testlerin ise en büyük dezavantajı çok uzun sürede sonuçların elde edilmesidir (124, 137). Polimeraz zincir reaksiyonu (PCR); kısa sürede sonuç elde edilmesi, duyarlılığı ve özgüllüğünün yüksek olması nedeniyle pek çok viral hastalığın tanısında sıklıkla kullanılmaktadır ancak hem pahalı ve hem sahaya uygun pratik bir test değildir. Biz bu çalışma ile sahaya yönelik, kolay yapılabilen ve hızlı sonuç veren bir uygulamanın çiftliklerde rutin hale gelmesini amaçliyoruz.

\section{Gerec ve Yöntem}

\section{Hayvanlar ve Özellikleri}

Bu çalışmada 200 adet, her iki cinsiyetten oluşan (precolostral) yeni doğan bir günlük ve 30 günlükten büyük buzağılar hayvan materyalini oluşturuldu. Hızlı test kitlerinin prensiplerine göre buzağılar ya kolostrum almadan yeni doğan hayvanlardan veya 30 günlükten büyük olan buzağılardan seçildi (Şekil 1). Testin yapılışı için seçilen hayvanlardan serum, plazma veya tam kan örnekleri hazırlandı. Kan örnekleri 10 ml'lik enjektörlerle vena jugularisten kan tüplerine alındı. Testin yapılışı için alınan kan örnekleri 4000 devirde 3 dakika santrifüj edilerek kan serumları elde edildi.

Çalışma kapsamına alınan tüm olgular hızlı ELISA prensibiyle çalışan ticari test kitleri (IDEXX BVDV Anigen Rapid Test Kit) aracılığıyla söz konusu hastalık (Bovine viral diare) yönünden değerlendirildi (Şekil 2, 3). Çalışma öncesi Mehmet Akif Ersoy Üniversitesi Deney Hayvanları Yerel Etik Kurulundan gerekli onay alındı. Tüm buzağıların eşgal, anemnez bilgileri, fiziksel muayene bulguları ve laboratuar analiz sonuçları kayıt edildi. Çalışmaya dahil edilecek buzağıların sahipleri bilgilendirilerek çalışmaya başlandı.
Test prosüdürü gerçekleştirmeden önce kullanılacak yeterli sayıda test kitleri sağlandı. Testtin yapılışı üretici firmanın belirttiği şekilde yapıldı.

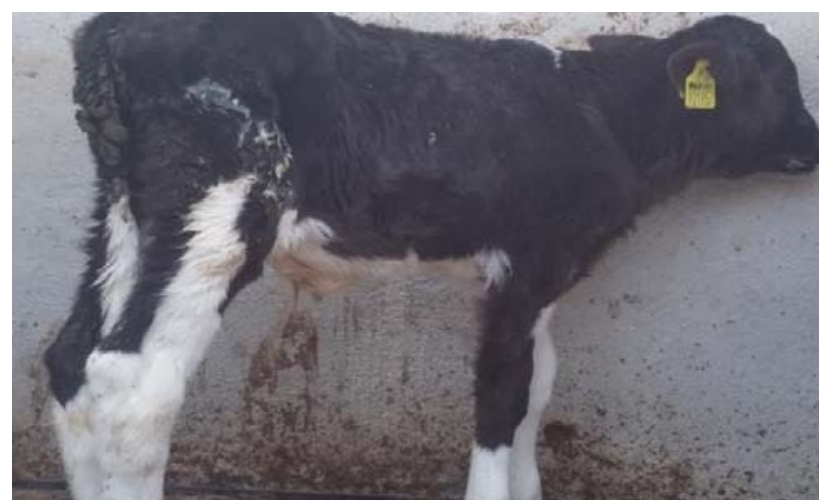

Şekil 1. 35 günlük ishal problemli ve tedaviye cevap alınamayan persiste enfekte (PI) holstein ırkı bir buzağı

\section{Testin Yapılışı}

Buzağılardan 10 ml'lik tek kullanımlık plastik enjektörle vena jugularisten kan alındı. Alınan örnekler 4000 devir ve 3 dakika santrifüj edilerek serumları ile çıkarıldı ve elde edilen serumlar ile test metoduna uyularak testler yapıldı. Alınan kan örnekleri ticari hızlı test kiti olan IDEXX BVD antijen (Ag) point- of care ile taranmıștır. Her bir serum örneği +4 derece buzdolabında muhafaza edilen test kiti ile test edildi. $\mathrm{Bu}$ amaçla kit plastik düz bir zemine yerleştirildi ambalajından çıkarılmış ve içinden çıkan plastik pipet ile 1 damla kan serumu kitin çukuruna damlatıldı. Teste ait olan buffer çözelti 1 dakika içerisinde 2 damla damlatıldı.15-20 dakika bekledikten sonra test sonucu okundu. Test kiti üzerinde kontrol ve test çizgileri kontrol edildi. Pozitif olan numunelerde çift çizgi görüldü (Şekil 2, Şekil 3).

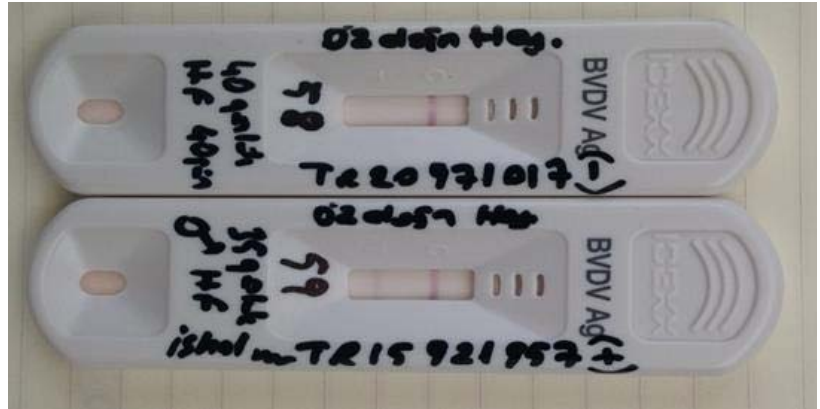

Şekil 2. 35 günlük buzağıya ait antijen pozitif test kiti (altta)

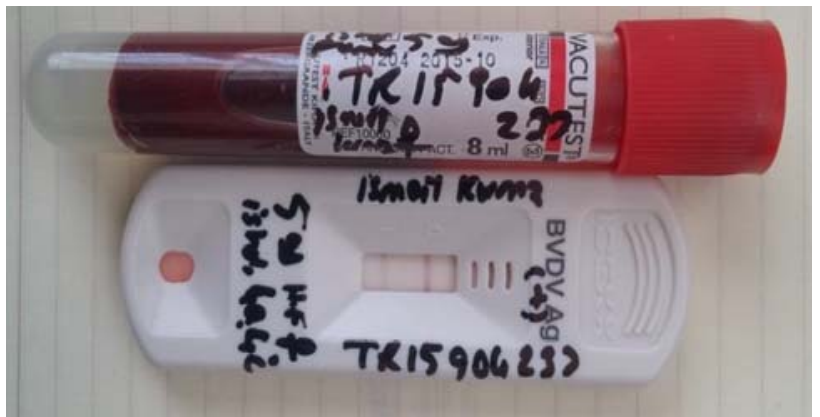

Şekil 3. 5 aylık dişi danaya ait persiste enfekte test sonucu 


\section{Bulgular}

Burdur ili ve çevresinde bulunan farklı işletmelerden kolostrum emmemiş veya 30 günlükten büyük buzağılardan 200 adet kan örneği toplandı. Alınan örneklerin 98 adedi dişi buzağılardan, 102 tanesi ise erkek buzağılardan alınd.

Tablo 1

Yaşa ve cinsiyete göre toplanan kan örnekleri

\begin{tabular}{|l|c|c|c|c|}
\hline Cinsiyet & 1 günlük & $\begin{array}{c}1-2 \\
\text { aylık }\end{array}$ & $\begin{array}{c}2-3 \\
\text { aylık }\end{array}$ & $\begin{array}{c}3 \text { aylık ve } \\
\text { üzeri }\end{array}$ \\
\hline Dişi & 9 & 41 & 25 & 2316 \\
\hline Erkek & 21 & 40 & 25 & \\
\hline
\end{tabular}

Tablo 2

Dişi hayvanlardan toplanan kan örneklerinin urk ve yaşa göre gruplandırılması

\begin{tabular}{|l|c|c|c|c|}
\hline \multicolumn{1}{|c|}{ Cinsiyet } & $\begin{array}{c}1 \\
\text { günlük }\end{array}$ & $\begin{array}{c}1-2 \\
\text { aylık }\end{array}$ & $\begin{array}{c}2-3 \\
\text { aylık }\end{array}$ & $\begin{array}{c}3 \text { aylık } \\
\text { ve üzeri }\end{array}$ \\
\hline Dişi & 9 & 41 & 25 & 23 \\
\hline Holstein & 3 & 32 & 22 & 23 \\
\hline Simental & 3 & 5 & 3 & - \\
\hline Simental Melezi & 2 & 2 & - & - \\
\hline Montofon & 1 & 2 & - & - \\
\hline Yerlikara & - & - & - & - \\
\hline
\end{tabular}

Tablo 3

Erkek hayvanlardan toplanan kan örneklerinin ırk ve yaşa göre gruplandırılması

\begin{tabular}{|l|c|c|c|c|}
\hline \multicolumn{1}{|c|}{ Cinsiyet } & $\begin{array}{c}1 \\
\text { günlük }\end{array}$ & $\begin{array}{c}1-2 \\
\text { aylık }\end{array}$ & $\begin{array}{c}2-3 \\
\text { aylık }\end{array}$ & $\begin{array}{c}3 \text { aylık } \\
\text { ve üzeri }\end{array}$ \\
\hline Dişi & 21 & 40 & 25 & 16 \\
\hline Holstein & 16 & 32 & 19 & 10 \\
\hline Simental & 3 & 7 & 4 & 1 \\
\hline Simental Melezi & 1 & 1 & 2 & 3 \\
\hline Montofon & 1 & - & - & 1 \\
\hline Yerlikara & - & - & - & 1 \\
\hline
\end{tabular}

Tablo 4

Persiste enfekte(PI) bulunan dişi ve erkek hayvanların gruplandırılması

\begin{tabular}{|l|l|l|l|}
\hline No & Cinsiyet & Yaş & Irk \\
\hline 1 & Dişi & 13,5 & Holstein \\
\hline 2 & Dişi & 5 ay & Holstein \\
\hline 3 & Dişi & 2 ay & Holstein \\
\hline 4 & Dişi & 1 ay & Holstein \\
\hline 5 & Dişi & 2 ay & Simental \\
\hline 6 & Dişi & 6 ay & Holstein \\
\hline 7 & Dişi & 5 ay & Holstein \\
\hline 8 & Dişi & 2 ay & Holstein \\
\hline 9 & Erkek & 1,5 ay & Holstein \\
\hline 10 & Erkek & 3 ay & Holstein \\
\hline 11 & Erkek & 35 günlük & Holstein \\
\hline 12 & Erkek & 2 ay & Holstein \\
\hline 13 & Erkek & 4 ay & Holstein \\
\hline
\end{tabular}

Toplanan örnekler arasında holstein ırkı buzağıların oranı diğer 1rklara göre yoğun olduğu görüldü. Holstein 1rkından olan örneklerin, 80 tanesi dişi buzağı, diğer 77 tanesi ise erkek buzağılardan oluştu. Simental ırkı dişi buzağı sayısı 11 adet, erkek simental ırkı buzağı sayısı ise
15 olarak saptandı. Simental melezi dişi örnekleri 4, erkek sayısı ise 7 buzağıdan oluştu. Montofon ırkı dişi buzağ sayısı 3, erkek buzağı 2; yerli kara dişi buzağı sayısı 0,erkek buzağı sayısı ise 1 adet oarak saptandı (Tablo 1 , Tablo 2, Tablo 3).

Persiste enfekte(PI) olarak saptanan dişi ve erkek hayvanların gruplandırılması ise Tablo 4 'te verilmiştir.

\section{Tartişma}

BVDV enfeksiyonu klinik olarak sindirim ve genital sistemi etkileyerek sığır yetiştiriciliğinde büyük ekonomik kayıplara neden olan multisistemik viral bir enfeksiyondur $(43,44,123)$.

Fetüsün gebeliğin ilk trimesterinde immun sistemi gelişmeden önce enfekte olması persiste enfeksiyonla (PI) sonuçlanır (38). Gebeliğin 90-170.günleri arasındaki transplasental BVD enfeksiyonlarında konjenital defektlerin meydana geldiği bildirilmektedir (119).

BVDV ile PI olan hayvanlar, etkeni yaşamları boyunca taşımaları ve tüm vücut salgılarıyla etrafa saçmaları nedeni ile BVD’nin en önemli bulaşma kaynağı olarak rol oynamaktadırlar (21). Sürü içi ve sürüler arası bulaşmada en tehlikeli etken PI hayvan alımı veya PI buzağı taşıyan ineklerin sürü içerisine dâhil edilmesidir (81). BVDV kontrolü yapılmayan sürülerle aynı merayı paylaşan başka sürülerdeki gebe hayvanlara da bulaşma şekillenebilir (122). Akut enfeksiyonlarda sürüdeki yayılım sınırlanabilse de enfeksiyonun yerleşik hal almasında erken gebe hayvanların (PI buzağı doğumuyla sonuçlanır) varlığı önemli rol oynar (81).

Persiste enfeksiyon bir generalize enfeksiyondur ve virüs birçok dokuda, özellikle epitaliyal ve endoteliyal sistem hücrelerinde bulunmakta, burun akıntısı, gözyaşı, tükrük, süt, semen, gaita, idrar gibi tüm sekret ve ekskretler ile saçılmaktadır. Uterus akıntısı, amniyotik sıvı ile kontamine plasenta da bulaşmada rol oynamaktadır (36).

Büyük bir sütçü sığır işletmesinde 4 yıl boyunca BVD virüs yönünden seronegatif olduklarının saptandığı ancak sürüye persiste viremik bir hayvanın girmesini takip eden 2 y1l içinde sürünün \% 85'inin enfeksiyonla tanıştığ ve çok yüksek oranlarda persiste viremik buzağ doğumlarının gözlemlendiği bildirilmiştir (94).

Sığır popülasyonlarında persiste hayvanların oranları kesin olarak bilinmemektedir. Amerika'da test edilen hayvanların \%1,7'sinde, İngiltere'de ise sağlıklı görünen sığırların \%0,4'ünde ve Kuzey Almanya'da 1000'in üzerinde damızlık sürüde yer alan 2317 sığırın \%1'inden daha azında persiste enfeksiyon bildirilmiştir (70). Bununla birlikte BVD virüs enfeksiyonunun yoğun olarak izlendiği sürülerde daha yüksek persiste oranları görülmüştür. Shimizu ve Satou (128) Japonya'da konjenital anomalilerin izlendiği bir bölgede \%8,1'inde; Taylor ve ark. (132) ise çok sayıda seronegatif sığırın katıldığı bir sürüde bir yıl boyunca doğan buzağıların $\% 9,1-12,7$ 'sinde persiste viremi saptadıkları bildirmişlerdir.

Bursa ilinde yapılan bir araştırmada 164 buzağ 1 test edilmiş ve 8 tanesinin (4,87\%) persiste enfekte olduğu saptanmıştır (145). 
Ülkemizde gerçekleştirilen çalışmalarda özellikle kapalı süt sığırı işletmelerdeki persiste enfeksiyon oranının $0,07 \%-0,5 \%$ arasında değişiklik gösterdiği belirlenmiştir (25). Seronegatif sürülere yeni giren BVD virüs enfeksiyonlarında virusun kısa sürede sürünün büyük bölümüne bulaşabileceği ve beklenmedik düzeyde $(12,7 \%)$ persiste enfekte buzağı doğumlarının gerçekleşebileceğini gösteren çalışmalar bulunmaktadır (132). Bizim çalışmamız Burdur ilindeki buzağılarda persiste enfekte buzağıların saptanması için yapılan ilk çalışmadır. Çalışmamızda persiste enfekte buzağı oranı $6,5 \%$ olarak saptanarak ülkemizde daha önce yapılmış çalışmaların oranına göre çok daha yüksek olduğu belirlenmiştir. Ayrıca bu çalışmada kullanılan hızlı test teşhis kitleri ilk defa kullanarak teşhiste çok pratik olduğu, hem sahada çalışan Veteriner Hekimler hem de hayvan sahipleri tarafından kolaylıkla kullanılabilen bir teşhis yöntemi olduğu ortaya konulmuştur.

\section{Sonuç ve öneriler}

Burdur yöresinde hayvancılığın ekonomik katkısı büyük olan süt sığırcılığı işletmelerinde BVD'li persiste enfekte buzağıların kolay ve pratik olarak belirlenmeleri ve gerekli önlemlerin zamanında alınması hastalığın yayılmasının engellemesi ve sürü sağlığının korunması için önem arz etmektedir.

Araştırma sonucunda 13 buzağıda antijen (+) olarak tespit edildi (6,5\%). Bunların 8 tanesi dişi, 5 tanesi erkekti. Tespit edilen persiste buzağıların aynı yaştaki diğer sağlıklı buzağılara göre daha az geliştikleri ve daha küçük oldukları gözlendi. Bazı buzağılarda solunum problemlerinin s1k sık görüldüğü, ara sıra ishal semptomları saptandığı dikkati çekti. BVDV pozitif bulduğumuz hayvanlardan en büyüğü 13,5 aylıktı. Anamnez alırken BVDV yönünden taranan işletmelerde koruyucu BVDV aşılamalarının yapılmadı̆̆ı hayvan sahiplerinden öğrenildi. BVDV pozitif bulunan işletmelerin 2 tanesinde daha önceki buzağılarda da gelişme geriliği ve sonuçta ölüm gerçekleştiği tespit edildi. Aynı çiftliklerde damızlık ineklerde infertilite ve döl tutmama sorunları olduğu hayvan sahiplerince bildirildi.

$\mathrm{Bu}$ çalışma ile Burdur'da ilk defa BVD virüs ile persiste enfekte buzağıların tanısı gerçekleştirildi ve prevalansına ilişkin değerler ortaya konuldu. Ayrıca hastalığın teşhisi için yine ilk defa antijen tespitine yönelik BVDV Hızlı Test Kitleri kullanıldı.

\section{Kaynaklar}

1. Ak. S., Fırat. İ., Bozkurt. H.H., Gülyüz. V., Ak. K. (2002). Trakya bölgesindeki sığırlarda bovine viral diarrhea virus (BVDV) infeksiyonlarının prevalansı ve persiste infekte (PI) hayvanların saptanması üzerine çalışmalar. Turkish Journal Veterinary and Animal Science. 26, 245-248.

2. Alenius, S., Lindberg, A., Larsson, B. (1996). A national approach to the control of bovine viral diarrhoea virus. In: 3rd ESVV symposium on pestivirus infections, 1997. Lelystad, The Netherlands, 19-20 September.
3. Alkan, F., Burgu, İ. (1993). Investigation on the insidence of Bovine Viral Diarrhoea Virus in calves in Turkey. Dtsch Tierarztl Wochenschr. 100,107-109.

4. Alves, D., Mc Ewen, B., Tremblay, R., Godkin, A., Anderson, N., Carman, S., Hazlett, M. (1996). Population diagnostics from an epidemic of bovine viral diarrhea in Ontario. In: International Symposium on Bovine Viral Diarrhoea Virus. A 50 year review, Cornell University, Ithaca, NY, USA, 71-74.

5. Bachofen, C., Braun, U., Hilbe, M., Ehrensperger, F., Stalder, H. Peterhans, E. (2010). Clinical appearance and pathology of cattle persistently infected with bovine viral diarrhoea virus of different genetic subgroups. Veterinary Microbiology. 141, 258-267.

6. Bachofen, C., Vogt, H.R., Stalder, H., Mathys, T., Zanoni, R., Hilbe, M., Schweizer, M., Peterhans, E. (2013). Persistent infections after natural transmission of bovine viral diarroea virus from cattle to goats and among goats. Veterinary Research. 44, 32 .

7. Baker, J.C. (1987). Bovine viral diarrhea virus: a review. Journal of the American Veterinary Medical Association. 190,1449-1458.

8. Baker, J.C. (1995) The clinical manifestations of bovine viral diarrhea infection. Veterinary Clinics of North America. Food Animal Practice. 11, 425-445.

9. Barber, D.M., Nettleton, P.F., Herring, J.A. (1985). Disease in a dairy herd associated with the introduction and spread of bovine virus diarrhoea virus. Veterinary Record, 117, 459-464.

10. Beaudeau, F., Assie, S., Seegers, H., Belloc, C., Sellal, E., Joly, A. (2001). Assessing the within-herd prevalence of cows antibody-positive to bovine viral diarrhoea virus with a blocking ELISA on bulk tank milk. Veterinary Record. 149, 236-240.

11. Becher, P., Orlich, M., Shannon, A.D., Horner, G., König, M., Thiel, H.J. (1997). Phylogenetic analysis of pestiviruses from domestic and wild ruminants. Journal of General Virology. 78, 1357-1366.

12. Belák, S., Ballagi-Pordány, A. (1993). Experiences on the application of the polymerase chain reaction in a diagnostic laboratory. Molecular and Cellular Probes. 7, 241-248.

13. Bennett, R.M., Done, J.T. (1986). Control of the bovine pestivirus syndrome in cattle: A case for social cost-benefit analysis? In: Society of Veteterinary Epidemiology and Preventive Medicine: Conference proceedings, Edinburgh, Scotland.

14. Bitsch, V., Ronsholt, L. (1995). Control of bovine viral diarrhea virus infection without vaccines. Veterinary Clinics of North America. Food Animal Practice. 11, 627-640.

15. Bolin, S.R., McClurkin, A.W., Cutlip, R.C., Coria, M.F. (1985). Response of cattle persistently infected with noncytopathic bovine viral diarrhea virus to vaccination for bovine viral diarrhea and to subsequent challenge exposure with cytopathic bovine viral diarrhea virus. American Journal of Veterinary Research. 46, 2467-2470.

16. Bolin, S.R., Ridpath, J.F. (1995). Assessment of protection from systemic infection or disease afforded by low to intermediate titers of passively acquired neutralizing antibody against bovine viral diarrhea 
virus in calves. American Journal of Veterinary Research. 56,755-759.

17. Braun, U., Landolt, G., Brunner, D., Giger, T. (1997). Epidemiologic studies of the occurrence of bovine virus diarrhea/mucosal disease in 2892 cattle in 95 dairy farms. Schweizer Archiv für Tierheilkunde. 139, 172-176.

18. Brock, K.V. (1995). Diagnosis of bovine viral diarrhea virus infections. Veterinary Clinics of North America. Food Animal Practice. 11, 549-561.

19. Brock, K.V., Grooms, D.L., Ridpath, J., Bolin, S.R. (1998). Changes in levels of viremia in cattle persistently infected with bovine viral diarrhea virus. Journal of Veterinary DiagnosticInvestigation. 10, 22 26.

20. Brock, K.V., Redman, D.R., Vickers, M.L., Irvine, N.E. (1991). Quantitation of bovine viral diarrhea virus in embryo transfer flush fluids collected from a persistently infected heifer. Journal of Veterinary Diagnostic Investigation. 3, 99-100.

21. Brownlie, J., Clarke, M.C., Howard, C.J. et al. (1987). Pathogenesis and epidemiology of bovine virus diarrhoea virüs infection of cattle. Annales de Recherches Veterinaires.18,157-166.

22. Brownlie, J., Clarke, M.C., Howard, C.J. (1989). Experimental infection of cattle in early pregnancy with a cytopathic strain of bovine virus diarrhoea virus. Research in Veterinary Science. 46, 307-311.

23. Brownlie, J., Hooper, L.B., Thompson, I., Collins, M.E. (1998). Maternal recognition of foetal infection with bovine virus diarrhoea virus (BVDV) - the bovine pestivirus. Clinical and Diagnostic Virology. 10, 141-150.

24. Bruschke, C.J., Haghparast, A., Hoek, A., Rutten, V.P., Wentink, G.H., Van Rijn, P.A., Van Oirschot, J.T. (1998). The immune response of cattle, persistently infected with noncytopathic BVDV, after superinfection with antigenically semi-homologous cytopathic BVDV. Veterinary Immunology and Immunopathology. 62, 37-50.

25. Burgu, İ., Alkan, F., Özkul, A., Yeşilbağ, K., Karaoğlu, T., Güngör, B. (2003). Türkiye'de süt sığırcılı̆̆ı işletmelerinde bovine viral diarrhoea virüs(BVDV)enfeksiyonunun epidemiyolojisi ve kontrolü.Ankara Üniversitesi Veteriner Fakültesi Dergisi. 50, 127-133.

26. Calister, C.H., Gould, E.A. (2003). Taxonomy of the virüs family flaviviridae. Advance in Virus Research. $59,1-19$

27. Carlsson, U., Belli, K. (1994). Border disease virus transmitted to sheep and cattle by a persistently infected ewe: epidemiology and control. Acta Veterinaria Scandinavica. 35, 79-88.

28. Carlsson, U. (1991). Border disease in sheep caused by transmission of virus from cattle persistently infected with bovine virus diarrhoea virus. Veterinary Record, 128,145-147.

29. Carlsson, U., Frederiksson, G., Alenius, S., Kindahl, H. (1989). Bovine Virus Diarrhoea Virus, a cause of early pregnancy failure in the cow. Journal of Veterinary Medicine. Series A. 36, 15-23.
30. Carman, S., Carr, N., DeLay, J., Baxi, M., Deregt, D., Hazlett, M. (2005). Bovine viral diarrhea virus in alpaca: abortion and persistent infection. Journal of Veterinary Diagnostic Investigation, 17, 589-593.

31. Charleston, B., Fary, M.D., Baigent, S., Carr, B.V., Morrison, W.I. (2001). Establishment of persistent infection with non-cytopathic bovine viral diarrhoea virus in cattle is associated with a failure to induce type I interferon. Journal of General Virology. 82, 1893-1897.

32. Corapi, W.V., Donis, R.O., Dubovi, E.J. (1988). Monoclonal antibody analyses of cytopathic and noncytopathic viruses from fatal bovine viral diarrhea virus infections. Journal of Virology. 62, 2823-2827.

33. Coria, M.F., McClurkin, A.W. (1978). Duration of active and colostrum-derived passive antibodies to bovine viral diarrhea virus in calves. Canadian Journal of Comparative Medecine, 42, 239-243.

34. Coria, M.F., McClurkin, A.W. (1978). Specific immune tolerance in an apparently healthy bull persistently infected with bovine viral diarrhea virus. Journal of the American Veterinary Medical Association, 172, 449-451.

35. Crevat, D., Vandenbergh, D., Chappuis, G., Lecomte, C., Renard, A. (1993). Five hours to identify immunotolerant cattle, persistently infected with bovine virus diarrhoea virus. Revue Scientifique et Technique, Office International des Epizooties. 12, 483-492.

36. Çabalar, M., Karaoğlu, T. (1999). Comparison of neutralization peroxidase-linked antibody(NPLA) assay and serum neutralization (SN) test for detection of antibodies to bovine viral diarrhea (BVD) virüs in cattle sera. Ankara Üniversitesi Veteriner Fakültesi Dergisi. 46, 249-255.

37. Depner, K., Hubschle, O.J., Liess, B. (1991). Prevalence of ruminant pestivirus infections in Namibia. Onderstepoort Journal of Veterinary Research, 58,107-109.

38. Done, J.T., Terlecki, S., Richardson, C., Harkness, J.W., Sands, J.J., Patterson, D.S., Sweasey, D., Shaw, I.G., Winkler, C.E., Duffel, S.J. (1980). Bovine virus diarrhoea-mucosal disease virus: pathogenicity for the fetal calf following maternal infection. Veterinary Record. 106, 473-479.

39. Donis, R.O. (1995). Molecular biology of bovine viral diarrhea virus and its interactions with the host. Veterinary Clinics of North America. Food Animal Practice. 11, 393-423.

40. Doyle, L.G., Heuschele, W.P. (1983). Bovine viral viarrhea virus-infection in captive exotic ruminants. Journal of The American Veterinary Medicine Association. 183, 1257-1259.

41. Drew, T.W., Yapp, F., Paton, D.J. (1999). The detection of bovine viral diarrhoea virus in bulk milk samples by the use of a single-tube RT-PCR. Veterinary Microbiology, 64,145-154.

42. Duffell SJ, Harkness JW(1985): Bovine virus diarrhoea-mucosal disease infection in cattle. Veterinary Record. 117, 240-245. 
43. Duffell, S.J., Sharp, M.W., Bates, D. (1986). Financial loss resulting from BVD-MD virus infection in a dairy herd. Veterinary Record. 118, 38-39.

44. Dufour, B., Repiquet, D., Touratier, A. (1999). Role of economic studies in animal health decisions: Example of the cost-benefit ratio of eradication of bovine viral diarrhea in France. Revue Scientifique et Technique, Office International des Epizooties. 18, 520-532.

45. Eddy, R.G. (2004). Alimentary conditions. In: Bovine Medicine-diseases and husbandry of cattle. Ed: Andrews AH, Blowey RW, Boyd H, Eddy RG. 2nd Ed. Blackwell Publishing, 853-857.

46. Edwards, S. (1990). The diagnosis of bovine virus diarrhoea mucosal disease in cattle. Revue Scientifique et Technique, Office International des Epizooties. 9, 115-130.

47. Ellis, J.A., West, K.H., Cortese, V.S., Myers, S.L., Carman, S., Martin, K.M., Haines, D.M. (1998): Lesions and distribution of viral antigen following an experimental infection of young seronegative calves with virulent bovine virus diarrhea virus-type II. Canadian Journalof Veterinary Research. 62,161-169.

48. Entrican, G., Dand, A., Nettleton, P.F. (1995). A double monoclonal antibody ELISA for detecting pestivirus antigen in the blood of viraemic cattle and sheep. Veterinary Microbiology. 43,65-74.

49. Fenton, A., Nettleton, P.F., Entrican, G., Herring, J.A., Malloy, C., Greig, A., Low, J. (1991). Identification of cattle infected with bovine virus diarrhoea virus using a monoclonal antibody capture ELISA. Archives of Virology Supplementum. 3, 169 174.

50. Foucras, G., Carnero, R., Perlier, C., Schelcher, F. (1996). Evaluation of an antigen-capture ELISA and practical consequences for diagnosis of BVDV infection. Revue de Médecine Vétérinaire. 147, 283290.

51. Fray, M.D., Paton, D.J., Alenius, S. (2000). The effects of bovine viral diarrhoea virus on cattle reproduction in relation to disease control. Animal Reproduction Science. 60-61, 615-627.

52. Gelfert, C.C. (1991). Epitkmiologische Unlersuchuingen iiber die Verbreilung des BVD. Virus bei Rindem in der Tür. lcei. Inaugural Dissenation, Hannover.

53. Gilbert, S.A., Burton, K.M., Prins, S.E., Deregt, D. (1999). Typing of bovine viral diarrhea viruses directly from blood of persistently infected cattle by multiplex PCR. Journal of Clinical Microbiology. 37, 2020-2023.

54. Givens, M.D., Galik, P.K., Riddell, K.P., Brock, K.V., Stringfellow, D.A. (2000). Replication and persistence of different strains of bovine viral diarrhea virus in an in vitro embryo production system. Theriogenology, 54,1093-1107.

55. Graham, D.A., Clegg, T.A., O’Sullivan, P., More, S.J. (2015). Survival time of calves with positive BVD virus results born during the voluntary phase of the Irish eradication. Preventive Veterinary Medicine. $119,123-133$.
56. Graham DA, McLaren IE and German A(1998): Evaluation of the suitability of a commercial bovine viral diarrhoea virus antigen capture ELISA for diagnostic testing. Veterinary Journal. 156, 149-154.

57. Gunn, H.M. (1993). Role of fomites and flies in the transmission of bovine viral diarrhoea virus. Veterinary Record. 132, 584-585.

58. Haines, D.M., Clark, E.G., Dubovi, E.J. (1992): Monoclonal antibody-based immunohistochemical detection of bovine viral diarrhea virus in formalinfixed, paraffin-embedded tissues. Veterinary Pathology. 29, 27-32.

59. Hamers, C., Dehan, P.. Couvreur, B., Letellier, C., Kerkhofs, P., Pastoret, P.P. (2001). Diversity among bovine pestiviruses. Veterinary Journal. 161, 112-122.

60. Hamers, C., Lecomte, C., Kulcsar, G., Lambot, M., Pastoret, P.P. (1998). Persistently infected cattle stabilise bovine viral diarrhea virus leading to herd specific strains. Veterinary Microbiology. 61, 177182.

61. Harkness, J.W. (1987). The control of bovine viral diarrhoea virus infection. Annales de Recherches Vétérinaires. 18,167-174.

62. Hewicker, M., Wohrmann, T., Fernandez, A., Trautwein, G., Liess, B., Moennig, V. (1990). Immunohistological detection of bovine viral diarrhoea virus antigen in the central nervous system of persistently infected cattle using monoclonal antibodies. Veterinary Microbiology. 23, 203-210.

63. Holmquist, G., Toomik, R., Rodgers, S., Lawrence, J., Ballagi, A. (2002). Laboratory diagnosis of BVDV by using ELISA for antigen and antibody detection. In: Detecting and controlling BVDV infections: Conference proceedings. Ames, Iowa, 4-5 April 2002. 27.

64. Horzenik, M.C. (1991). Pestivirus-taxonomic perspectives. Archives of Virology, Suppl. 3, 1-5.

65. Houe, H. (1999). Epidemiological features and economical importance of bovine virus diarrhoea virus (BVDV) infections. Veterinary Microbiology. 64, 89107.

66. Houe, H., Meyling, A. (1991). Prevalence of bovine virus diarrhea (BVD) in 19 Danish dairy herds and estimation of incidence of infection in early pregnancy. Preventive Veterinary Medicine.11, 9-16.

67. Houe, H., Pedersen, K.M., Meyling, A. (1992). A computerized spreadsheet model for calculating total annual losses due to bovine viral diarrhoea virus infection in dairy herds and sensitivity analysis of selected parameters. In: Proceedings of the 2nd ESVV symposium on ruminant pestiviruses, Annecy, France, 179-184.

68. Houe, H., Pedersen, K.M., Meyling, A. (1993). The effect of bovine virus diarrhea virus infection on conception rate. Preventive Veterinary Medicine. 15, 117-123.

69. Houe, H. (1992). Serological analysis of a small herd sample to predict presence or absence of animals persistently infected with bovine viral diarrhoea virus (BVDV) in dairy herds. Research in Veterinary Science. 53, 320-323. 
70. Howard, C.I., Clarke, M.C., Brownlie, J. (1989). Protection against respiratory infection with bovine virus diarrhoea virus by passively acquired antibody. Veterinary Microbiology. 19, 195-203.

71. Howard, C.J. (1990). Immunological responses to bovine virus diarrhoea virus infections. Revue Scientifique et Technique, Office International des Epizooties. 9, 95-103.

72. Husu, J., Kulkas, L. (1993). The control programmes against contagious bovine leukosis and BVDV. Suomen Eläinlääkärilehti, 99,482-483.

73. İssi, M., Gülaçtı, İ., Kızıl, Ö., Karapınar, T., Bulut, H., Gül, Y. (2006). Kliniğimizde Gözlenen Reverse Transkriptaz-Polimeraz Zincir Reaksiyonu (RT-PCR) İle Doğrulanan Mukoza Hastalığı Olguları. Fırat Üniversitesi Sağlık Bilimleri Veteriner Dergisi. 20, 3, 253-258.

74. Kirkland, P.D., McGowan, M.R., Mackintosh, S.G., Moyle, A. (1997). Insemination of cattle with semen from a bull transiently infected with pestivirus. Veterinary Record. 140, 124-127.

75. Kirkland, P.D., Richards, S.G., Rothwell, J.T., Stanley, D.F. (1991). Replication of bovine viral diarrhoea virus in the bovine reproductive tract and excretion of virus in semen during acute and chronic infections. Veterinary Record. 128, 587-590.

76. Kramps, J.A., van Maanen, C., van de Wetering, G., Stienstra, G., Quak, S., Brinkhof, J., Ronsholt, L., Nylin, B. (1999). A simple, rapid and reliable enzyme-linked immunosorbent assay for the detection of bovine virus diarrhoea virus (BVDV) specific antibodies in cattle serum, plasma and bulk milk. Veterinary Microbiology. 64, 135-144.

77. Kummerer, B.M., Tautz, N., Becher, P., Thiel, H., Meyers, G. (2000). The genetic basis for cytopathogenicity of pestiviruses. Veterinary Microbiology. 77, 117-128.

78. Lang-Ree, J.R., Vatn, T., Kommisrud, E., Loken, T. (1984). Transmission of bovine viral diarrhoea virus by rectal examination. Veterinary Record. 135, 412413.

79. Larsson, B., Niskanen, R., Alenius, S. (1984). Natural infection with bovine virus diarrhea virus in a dairy herd- a spectrum of symptoms including early reproductive failure and retained placenta. Animal Reproduction Science. 36, 37-48.

80. Lindberg, A.L.E., Alenius, S. (1999). Principles for eradication of bovine viral diarrhoea virus (BVDV) infections in cattle populations. Veterinary Microbiology. 64, 222.

81. Lindberg, A.L.E. (2003). Bovine viral diarrhoea virus infections and its control. A review, Veterinary Quarterly. 25, 1, 1-16.

82. Lindberg, A. (2002). Epidemiology and eradication of bovine viral diarrhoea virus infections. Studies on transmission and prenatal diagnosis of persistent infection. In Thesis: Acta Universitatis Agriculturae Sveciae, Veterinaria 132, 2002, Swedish University of Agriculural Sciences, Uppsala.

83. Lindberg, A., Groenendaal, H., Alenius, S., Emanuelson, U. (2001). Validation of a test for dams carrying foetuses persistently infected with bovine viral-diarrhoea virus based on determination of antibody levels in late pregnancy. Preventive Veterinary Medicine. 51, 199-214.

84. Luzzago, C., Bandi, C., Bronzo, V., Ruffo, G., Zecconi, A. (2001). Distribution pattern of bovine viral diarrhoea virus strains in intensive cattle herds in Italy. Veterinary Microbiology. 83, 265-274.

85. Mahlum, C.E., Haugerud, S., Shivers, J.L., Rossow, K.D., Goyal, S.M., Collins, J.E., Faaberg, K.S. (2002). Detection of bovine viral diarrhea virus by TaqMan reverse transcription polymerase chain reaction. Journal of Veterinary Diagnostic Investigation. 14, 120-125.

86. Mars, M.H., Bruschke, C.J., van Oirschot, J.T. (1999). Airborne transmission of BHV1, BRSV, and BVDV among cattle is possible under experimental conditions. Veterinary Microbiology. 66, 97-207.

87. McClurkin, A.W., Bolin, S.R., Coria, M.F. (1985). Isolation of cytopathic and noncytopathic bovine viral diarrhea virus from the spleen of cattle acutely and chronically affected with bovine viral diarrhea. Journal of the American Veterinary Medical Association. 186, 568-569.

88. McClurkin, A.W., Coria, M.F., Cutlip, R.C. (1979). Reproductive performance of apparently healthy cattle persistently infected with bovine viral diarrhea virus. Journal of the American Veterinary Medical Association. 174, 1116-1119.

89. McGowan, M.R., Kirkland, P.D. (1995). Early reproductive loss due to bovine pestivirus infection. British Veterinary Journal. 151, 263-270.

90. McGowan, M.R., Kirkland, P.D., Richards, G.S., Littlejohns, I.R. (1993). Increased reproductive losses in cattle infected with bovine pestivirus around the time of insemination. Veterinary Record. 133, 39-43.

91. Meyling, A., Jensen, A.M. (1988). Transmission of bovine virus diarrhoea virus (BVDV) by artificial insemination (AI) with semen from a persistentlyinfected bull. Veterinary Microbiology. 17, 97-105.

92. Mignon, B., Waxweiler, S., Thiry, E., Boulanger, D., Dubuisson, J., Pastoret, P.P. (1992). Epidemiological evaluation of a monoclonal ELISA detecting bovine viral diarrhoea pestivirus antigens in field blood samples of persistently infected cattle. Journal of Virological Methods. 40, 85-93.

93. Moennig, V., Liess, B. (1995). Pathogenesis of intrauterine infections with bovine viral diarrhea virus. Veterinary Clinics of North America. Food Animal Practice. 11, 477-87.

94. Moerman, A., Strayer, P.J., de Jong, M.C., Quak, J., Baanvinger, T., van Oirschot, J.T. (1992). A longterm epidemiological study of bovine virüs diarrhoea virüs infections in a large herd of dairy cattle. Proceedings of the Seconds Symposium on pestivirus. ESVV/Annecy, France.

95. Moerman, A., Strayer, P.J., de Jong, M.C., Quak, J., Baanvinger, T., van Oirschot, J.T. (1994). Clinical consequences of a bovine virus diarrhoea virus infection in a dairy herd: a longitudinal study. Veterinary Quarterly. 16,115-119.

96. Nelson, D.D., Dark, M.J., Bradway, D.S., Ridpath, J.F., Call, N., Haruna, J., Rurangirwa, F.R., 
Evermann, J.F. (2008). Evidence for persistent Bovine viral diarrhea virus infection in a captive mountain goat (Oreamnos americanus). Journal of Veterinary Diagnostic Investigation. 20, 752-759.

97. Nettleton, P.F. (1990). Pestivirus infections in ruminants other than cattle. Revue Scientifique et Technique, Office International des Epizooties. 9, 131-150.

98. Niskanen, R., Alenius, S., Larsson, B., Jacobsson, S.O. (1991). Determination of level of antibodies to bovine virus diarrhoea virus (BVDV) in bulk tank milk as a tool in the diagnosis and prophylaxis of BVDV infections in dairy herds. Archives of Virology, Supplementum. 3, 245-251.

99. Niskanen, R., Lindberg, A. (2003). Transmission of bovine virus diarrhoea virus by unhygienic vaccination procedures, ambient air and by contaminated pens. Veterinary Journal. 165, 251-259.

100. Njaa, B.L., Clark, E.G., Janzen, E., Ellis, J.A., Haines, D.M. (2000). Diagnosis of persistent bovine viral diarrhea virus infection by immunohistochemical staining of formalin-fixed skin biopsy specimens. Journal of Veterinary Diagnostic Investigation. 12, 393-399.

101. Oberst, R.D. (1993). Viruses as teratogens. Veterinary Clinics of North America. Food Animal Practice. 9, 23-31.

102. Odeon, A.C., Kelling, C.L., Marshall, D.J., Estela, E.S., Dubovi, E.J., Donis, R.O. (1999). Experimental infection of calves with bovine viral diarrhea virus genotype II (NY-93). Journal of Veterinary Diagnostic Investigation. 11, 221-228.

103. Ok, M. (2010). Bovine viral diyare mukozal hastalığı. İn: Cebecioğlu A.(Editor).Ruminantlarda Yaz Sorunları Beslenme ve Hastalıkları. İstanbul: infovet, 72-81.

104. Onodera, K., d'Offay, J., Melcher, U. (2002). Nylon membrane-immobilized PCR for detection of bovine viruses. Biotechniques. 32,74-76, 78, 80.

105. Özkul, A., Yeşilbağ, K., Burgu, İ. (2002). Comparison of four diagnostic techniques for detecting Bovine Virus Diarrhoea Virus (BVDV) in buffy coat samples after long-term storage. Turkish Journal of Veterinary Animal Science. 26(5), 1043 1048.

106. Palfi, V., Houe, H., Philipsen, J. (1993). Studies on the decline of bovine virus diarrhoea virus (BVDV) maternal antibodies and detectability of BVDV in persistently infected calves. Acta Veterinaria Scandinavica. 34, 105-107.

107. Passler, T., Ditchkoff, S.S., Givens, M., Brock, K.V., DeYoung, R.W., Walz, P.H. (2010). Transmission of bovine viral diarrhea virus among white-tailed deer (Odocoileus virginianus). Veterinary Research. 41, 20.

108. Patel, J.R., Shiletto, R.W., Williams, J., Alexander, D.C. (2002). Prevention of transplacental infection of bovine foetus by bovine viral diarrhoea virus through vaccination Brief Report. Archives of Virology. 147, 2453-2463.

109. Paton, D.J., Carlsson, U., Lowings, J.P., Sands, J.J., Vilcek, S., Alenius, S. (1995). Identification of herdspecific bovine viral diarrhoea virus isolates from infected cattle and sheep. Veterinary Microbiology. 43, 283-294.

110. Potgieter, L.N.D. (1995). Immunology of bovine viral diarrhea virus. Veterinary Clinics of North America. Food Animal Practice. 11, 501.

111. Quaife, T. (1996). Improper vaccination compounds BVD problem. Dairy Herd Management. 33(10), 12 16.

112. Radwan, G.S., Brock, K.V., Hogan, J.S., Smith, K.L. (1995). Development of a PCR amplification assay as a screening test using bulk milk samples for identifying dairy herds infected with bovine viral diarrhea virus. Veterinary Microbiology. 44, 77-91.

113. Reimann, I., Semmler, I., Beer, M. (2007). Replicons of bovine viral diarrhea virüs are capable of inducing a protective immune response. Virology. 366, 377-386.

114. Renshaw, R.W., Ray, R., Dubovi, E.J. (2000). Comparison of virus isolation and reverse transcription polymerase chain reaction assay for detection of bovine viral diarrhea virus in bulk milk tank samples. Journal of Veterinary Diagnostic Investigation. 12, 184-186.

115. Ridpath, J.E., Neill, J.D., Endsley, J., Roth, J.A. (2003). Effect of passive immunity on the development of a protective immune response against bovine viral diarrhea virus in calves. American Journal of Veterinary Research. 64,65-69.

116. Ridpath, J.F., Neill, J.D., Frey, M., Landgraf, J.G. (2000). Phylogenetic, antigenic and clinical characterization of type 2 BVDV from North America. Veterinary Microbiology. 77, 145-155.

117. Ridpath, J. (2012). Preventive strategy for BVDV infection in North America. Japanese Journal of Veterinary Research, 60 (supplement), 41-49.

118. Roeder, P.L., Jeffrey, M., Cranwell, M.P. (1986). Pestivirus fetopathogenicity in cattle: changing sequelae with fetal maturation. Veterinary Record. $118,44-48$.

119. Radostits, O.M., Gay, C.C., Hinchliff, K.W., Constable, P.D. (2008). Veterinary Medicine.10th Edition, Edinburgh, London, NewYork, Oxford, Philadephia, StLouis, Sydney, Toronto: Saunders Elsevier.

120. Rossmanith, W., Vilcek, S., Wenzl, H., Rossmanith, E., Loitsch, A., Durkovic, B., Strojny, L., Paton, D.J. (2001). Improved antigen and nucleic acid detection in a bovine virus diarrhoea eradication program. Veterinary Microbiology, 81, 207-218.

121. Rufenacht, J., Schaller, P., Audige, L., Knutti, B., Kupfer, U., Peterhans, E. (2001). The effect of infection with bovine viral diarrhea virus on the fertility of Swiss dairy cattle. Theriogenology. 56, 199-210.

122. Rufenacht, J., Schaller, P., Audige, L., Strasser, M., Peterhans, E. (2000). Prevalence of cattle infected with bovine viral diarrhoea virus in Switzerland. Veterinary Record. 147, 413-417.

123. Rush, D.M., Thurmond, M.C., Munoz-Zanzi, C.A., Hietala, S.K. (2001). Descriptive epidemiology of postnatal bovine viral diarrhea virus infection in intensively managed dairy heifers. Journal of the 
American Veterinary Medical Association. 219, 1426-1431.

124. Sandvik, T. (1999). Laboratory diagnostic investigations for bovine viral diarrhoea virus infections in cattle. Veterinary Microbiology. 64, 123134.

125. Scherer, C.F., Flores, E.F., Weiblen, R., Caron, L., Irigoyen, L.F., Neves, J.P., Maciel, M.N. (2001). Experimental infection of pregnant ewes with bovine viral diarrhea virus type-2 (BVDV-2): effects on the pregnancy and fetus. Veterinary Microbiology. 79, 285-299.

126. Schlafer, D.H., Gillespie, J.H., Foote, R.H., Quick, S., Pennow, N.N., Dougherty, E.P., Schiff, E.I., Allen, S.E., Powers, P.A., Hall, C.E., Voss, H. (1990). Experimental transmission of bovine viral diseases by insemination with contaminated semen or during embryo transfer. Deutsche Tierärztliche Wochenschrift. 97, 68-72.

127. Schreiber, P., Dubois, F., Dreze, F., Lacroix, N., Limbourg, B., Coppe, P. (1999). Prevalence of bovine virus diarrhoea virus infection in Belgian white blue cattle in southern Belgium. Veterinary Quarterly. 21, 28-32.

128. Ståhl, K., Alenius, S. (2012). BVDV control and eradication in Europe-an update. Japanese Journal of Veterinary Research, 60 (supplement), 31-39.

129. Stelwagen, J., Dijkhuizen, A.A. (1998). BVD outbreak can be costly: a case report. Tijdschrift voor Diergeneeskunde, 123, 283-286.

130. Şimşek, A., Öztürk, F. (1997). Klinik olarak sağlıklı sığır sürülerinde persiste bovine viral diarrhoe virus enfeksiyonlarının araştırılması ve epizootiyolojik önemi. Veteriner Bilimleri Dergisi. 13, 113-119.

131. Tautz, N., Meyers, G., Thiel, H.J. (1998). Pathogenesis of mucosal disease, a deadly disease of cattle caused by a pestivirus. Clinical and Diagnostic Virology. 10, 121-127.

132. Taylor, L.F., Janzen, E.D., Ellis, J.A., van den Hurk, J.V., Ward, P. (1997). Performance, survival, necropsy, and virological findings from calves persistently infected with the bovine viral diarrhea virus originating from a single Saskatchewan beef herd. Canadian Veterinary Journal. 38, 29-37.

133. Terpstra, C., Wensvoort, G. (1997). A congenital persistent infection of bovine virus diarrhoea virus in pigs: clinical, virological and immunological observations. Veterinary Quarterly. 19, 97-101.

134. Thiel, H.J., Meyers, G., Stark, R., Tautz, N., Rumenapf, T., Unger, G., Conzelman, K. (1993). Molecular characterization of positive-strand RNA viruses: pestiviruses and the porcine reproductive and respiratory syndrome virus (PRRSV). Archives of Virology, Supplementum. 7, 41-52.
135. Thurmond, M.C., Munoz-Zanzi, C.A., Hietala, S.K. (2001). Effect of calfhood vaccination on transmission of bovine viral diarrhea virus under typical drylot dairy conditions. Journal of the American Veterinary Medical Association. 219, 968-975.

136. Uttenthal, Å., Grøndahl, C., Hoyer, M.J., Houe, H., van Maanen, C., Rasmussen, T.B., Larsen, L. (2005). Persistent BVDV infection in mousedeer infects calves - do we know the reservoirs for BVDV. Preventive Veterinary Medicine. 72, 87-91.

137. Valle, P.S., Martin, S.W., Skjerve, E. (2001). Time to first calving and calving interval in bovine virus diarrhoea virus (BVDV) sero-converted dairy herds in Norway. Preventive Veterinary Medicine. 51, 17-36.

138. Van Campen, H. (2010). Epidemiology and control of BVD in the U.S. Veterinary Microbiology. 142, 94-98.

139. Van Campen, H., Ridpath, J., Williams, E., Cavender, J., Edwards, J., Smith, S., Sawyer, H. (2001). Isolation of bovine viral diarrhea virus from a free-ranging mule deer in Wyoming. Journal of Wild Animal Diseases. 37, 306-311.

140. Van Campen, H., Woodard, L. (1997). Fetal infection may not be preventable with BVDV vaccines. Journal of the American Veterinary Medical Association. 210, 480.

141. Van Oirschot, J.T. (1999). Diva vaccines that reduce virus transmission. Journal of Biotechnology. 73, 195-205.

142. Van Oirschot, J.T. (2001). Present and future of veterinary viral vaccinology: a review. Veterinary Quarterly. 23,100-108.

143. Vilcek, S., Alenius, S., Paton, D.J., Mittelholzer, C., Bela, S. (1999). Genetic clustering of bovine viral diarrhoea viruses in cattle farms: genetic identification and analysis of viruses directly from cattle sera. Veterinary Journal. 158, 33-38.

144. Vilček, S., Paton, D.J., Rowe, L.W., Anderson, E.C. (2000). Typing of pestiviruses from eland in Zimbabwe. Journal of Wild Animal Diseaes. 36, 165168.

145. Yeșilbağ, K., Alpay, G.,Tuncer, P. (2012). Bir süt sığırcılığ 1 işletmesinde bovine viral diarrhoea (BVD) virus enfeksiyonunun kontrol ve eliminasyonu. Uludağ Üniversitesi Veteriner Fakültesi Dergisi. 31, 11-7.

146. Waage, S., Krogsrud, J., Nyberg, O. (1994). The Norwegian programme for eradication of bovine viral diarrhoea/mucosal disease. In 18th World Buiatrics Congress: 26th Congress of the Italian Association of Buiatrics, Augustus 29 - September 2, 1994, Bologna, Italy. 773-775.

Стаття надійшла до редакиії 12.10.2016 